\title{
EVALUASI KONDISI LINGKUNGAN PERAIRAN KAWASAN PULAU ABANG, GALANG BARU, BATAM BERDASARKAN ANALISA INDEKS STORET DAN SIMILARITAS CANBERA
}

\author{
Oleh : \\ Suhendar I Sachoemar \\ Deputi Bidang Teknologi Agroindustri dan Bioteknologi \\ Badan Pengkajian dan Penerapan Teknologi
}

\begin{abstract}
Evaluation of the water quality status at Abang Island Region was conducted by using the STORET and Canbera Similarity Indeks during Mei, June and October 2006. This analysis result shows that the water quality within this region was within the range of good to moderate. This condition indicats that the water quality status is still suitable to support the marine biotic life. During May, the water quality was good, but in June and October was decreased due to the increasing of the organic material transported by land surface run off driven by precipitation as response to the seasonal change.
\end{abstract}

Katakunci : Kualitas air, Pulau Abang, Indeks Storet, Indeks Similaritas Canbera.

\section{PENDAHULUAN}

Pulau Abang termasuk ke dalam Gugusan Kepulauan Riau yang memiliki 42 pulau antara lain Pulau Abang Besar, Pulau Abang Kecil, Petong, Galang Baru, Nguan, Teleje, Penggelap, Pasir Bukul dan gugusan pulau-pulau kecil lainnya (Gambar 1). Kawasan ini secara oseanografi dipengaruhi perairan Laut Cina Selatan dan Selat Malaka yang perubahannya dipengaruhi musim (Nontji, 1987; Tomascik et al, 1997).

Batam merupakan kawasan pertumbuhan yang dinamis dan dikenal sebagai sebuah kawasan industri, termasuk perdagangan, pariwisata dan alih kapal (transhipment). Dalam perencanaan kawasan perairan Kota Batam, sesuai dengan Rencana Umum Tata Ruang Wilayah (RUTRW) Kota Batam, kawasan Pulau Abang akan dijadikan sebagai kawasan budidaya laut (Marikultur) dan pariwisata (Bappeko Batam, 2006).

Pengembangan industri budidaya laut dan pariwisata ini diharapkan mampu membuka lapangan kerja baru melalui pengembangan berbagai peluang bisnis dan dapat meningkatkan kesejahteraan masyarakat sekitarnya. Namun dalam jangka panjang harapan tersebut bisa menjadi tidak berarti apabila kegiatan yang dilakukan di kawasan perairan Pulau Abang tidak dikelola dengan baik, sehingga dapat mempercepat penurunan kualitas lingkungan perairan di kawasan ini. Untuk mendukung keberlanjutan pengembangan budidaya laut di Pulau Abang, perlu dilakukan penelitian tentang kondisi lingkungan perairan di kawasan ini yang dalam tulisan ini disajikan berdasarkan tinjauan parameter fisika dan kimia.

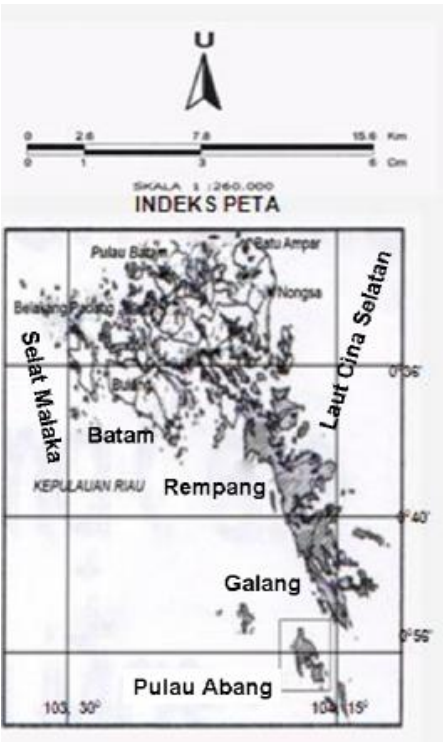

Gambar 1. Lokasi Pulau Abang

\section{METODA PENELITIAN}

\subsection{Pengumpulan Data}

Pengumpulan data dalam penelitian ini dilakukan melalui survei langsung di perairan Pulau Abang, Galang Baru, Provinsi Kepulauan Riau. Penelitian dilakukan pada bulan Mei, Juni dan Oktober 2006. Parameter fisik dan kimia temperatur, salinitas, $\mathrm{pH}$ dan $\mathrm{DO}$ diukur langsung di lapangan dengan menggunakan water quality checker YSI-85 (OCST). Kecerahan diukur dengan menggunakan seichi disk. Sementara parameter TSS, TDS, nitrat $\left(\mathrm{NO}_{3}-\mathrm{N}\right)$, nitrit $\left(\mathrm{NO}_{2}-\mathrm{N}\right)$, ammonia $\left(\mathrm{NH}_{3}-\mathrm{N}\right)$, fosfat dan $\mathrm{COD}$ di analisa di laboratorium dari sampel air yang 
diambil dari 8 stasiun pengamatan (Gambar 2) dengan menggunakan metode APHA (1979). Parameter yang diukur dan alat yang digunakan dalam analisa dan pengukuran di lapangan terlihat pada Tabel 1.

Tabel 1. Parameter Dan Alat Yang Digunakan Dalam Analisa Dan Pengukuran Parameter Lingkungan Perairan Di Pulau Abang

\begin{tabular}{|c|c|c|c|}
\hline No & Parameter & Unit & Alat \\
\hline & Fisik & & \\
\hline 1 & Suhu & ${ }^{\circ} \mathrm{C}$ & YSI.85 (OCST) \\
\hline 2 & Kecerahan & $\mathrm{m}$ & Secchi disk \\
\hline 3 & Salinitas & psu & YSI.85 (OCST) \\
\hline 4 & $\mathrm{pH}$ & - & $\mathrm{pH}$-meter \\
\hline 5 & TSS & $\mathrm{mg} / \mathrm{l}$ & $\begin{array}{l}\text { Vacuum pump dan } \\
\text { millipore } 0,45 \text { um }\end{array}$ \\
\hline \multirow[t]{2}{*}{6} & TDS & $\mathrm{mg} / \mathrm{l}$ & TDS-meter \\
\hline & Kimia & & \\
\hline 8 & DO & $\mathrm{mg} / \mathrm{l}$ & YSI.85 (OCST) \\
\hline 9 & Nitrat $\left(\mathrm{NO}_{3}-\mathrm{N}\right)$ & $\mathrm{mg} / \mathrm{l}$ & Spektrofotometer \\
\hline 10 & Ammonia $\left(\mathrm{NH}_{3}-\mathrm{N}\right)$ & $\mathrm{mg} / \mathrm{l}$ & Spektrofotometer \\
\hline 11 & Nitrit $\left(\mathrm{NO}_{2}-\mathrm{N}\right)$ & $\mathrm{mg} / \mathrm{l}$ & Spektrofotometer \\
\hline 12 & Orthofosfat & $\mathrm{mg} / \mathrm{l}$ & Spektrofotometer \\
\hline 13 & COD & $\mathrm{mg} / \mathrm{l}$ & Titrasi \\
\hline
\end{tabular}

\subsection{Analisa Data}

Data parameter fisika-kimia kemudian dianalisa dengan menggunakan beberapa model analisis data kualitas air sebagai berikut :

\subsubsection{Indeks STORET}

Perhitungan indeks STORET dilakukan untuk mengetahui kualitas perairan di setiap titik lokasi pengamatan sehingga diperoleh gambaran yang lebih komprehensif mengenai kondisi kualitas perairan di lokasi tersebut. Penilaian indeks ini dilakukan dengan menjumlah dua kategori parameter kualitas air yaitu parameter fisika dan kimia. Penilaian setiap parameter dibedakan berdasarkan jumlah sampel air. Setiap parameter yang diukur dirata-ratakan dan didapatkan angka maksimum dan minimumnya (Tabel 2). Ketiga nilai ini kemudian dibandingkan dengan nilai baku mutu air laut untuk biota laut dan wisata bahari yang ditetapkan Menteri Negara Lingkungan Hidup dalam Keputusan Nomor 51 tahun 2004, kemudian diberi skor. Langkah-langkah perhitungan indeks STORET adalah sebagai berikut :

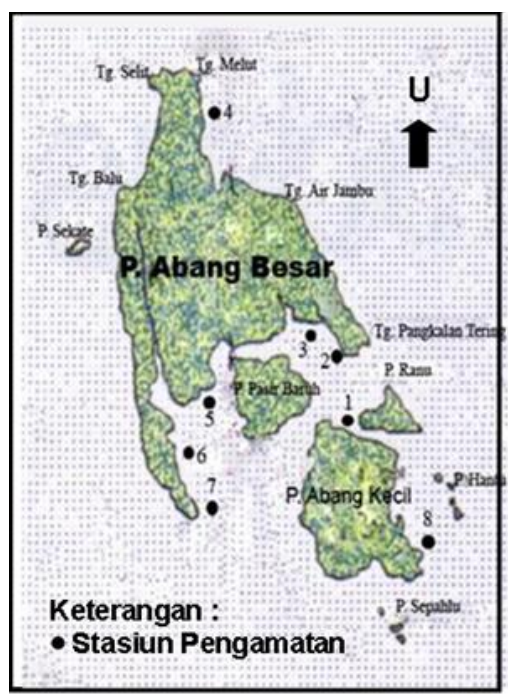

Gambar 2. Stasiun Sampling di Pulau Abang

Tabel 2. Penentuan Sistem Skor Untuk Menentukan Status Mutu Perairan Berdasarkan Indeks STORET (Moriber, 1974; Canter 1977)

\begin{tabular}{|c|c|c|c|c|}
\hline \multirow{2}{*}{$\begin{array}{c}\text { Jumlah } \\
\text { Sampel Ai }\end{array}$} & \multirow[b]{2}{*}{ Nilai } & \multicolumn{3}{|c|}{ Parameter } \\
\hline & & Fisika & Kimia & Biolog \\
\hline$<10$ & Maksimum & -1 & -2 & -3 \\
\hline & \begin{tabular}{|l|} 
Minimum \\
\end{tabular} & -1 & -2 & -3 \\
\hline & Rata-Rata & -3 & -6 & -9 \\
\hline$\geq 10$ & Maksimum & -2 & -4 & -6 \\
\hline & Minimum & -2 & -4 & -6 \\
\hline & Rata-Rata & -6 & -12 & -18 \\
\hline
\end{tabular}

a. Membuat tabel hasil analisis kualitas air yang memuat seluruh nilai parameter fisika dan kimia (suhu, kecerahan, salinitas, TSS, pH, DO, ammonia, ortofosfat) dengan mencantumkan nilai maksimum, minimum dan rata-rata hasil pengukuran setiap parameter di lokasi pengamatan

b. Membandingkan nilai minimum, maksimum, dan rata-rata hasil pengukuran dari setiap parameter terhadap baku mutu masing-masing seseuai dengan Keputusan Menteri Negara Lingkungan Hidup No. 51 Tahun 2004.

c. Memberikan skor terhadap masing-masing parameter tersebut seperti berikut :

a) Jika hasil pengukuran memenuhi nilai baku mutu (hasil pengukuran kurang dari baku mutu) maka diberi skor 0 (nol).

b) Skor $\left(\begin{array}{lll}-1 & \mathrm{~s} / \mathrm{d} & -9\end{array}\right)$ jika nilai minimum, maksimum, atau rata-rata tidak memenuhi baku mutu yang ditetapkan dengan jumlah sampel air yang dianalisis $<10$. 
c) Skor (-2 s/d -18) Jika nilai minimum, maksimum atau rata-rata parameter pengukuran tidak memenuhi $(\geq)$ baku mutu yang ditetapkan dengan jumlah sampel air yang dianalisis $\geq 10$.

Jika nilai indeks STORET mendekati nol, mengindikasikan semakin baik kualitas air dan sebaliknya jika jumlah nilai menjauhi nol, mengindikasikan semakin buruknya kualitas air. Uraian sistem pemberian nilai bagi setiap nilai maksimum, minimum, dan rata-rata masing-masing parameter fisika, kimia, dan biologi berdasarkan jumlah sampel air yang digunakan ditampilkan dalam Tabel 3.

Tabel 3. Penentuan Status Mutu Air (Canter, 1977)

\begin{tabular}{|c|l|}
\hline \multicolumn{1}{|c|}{ Skor } & \multicolumn{1}{c|}{ Kriteria } \\
\hline 0 & Baik Sekali \\
\hline-1 s/d -18 & Baik \\
\hline-19 s/d -36 & Sedang \\
\hline-37 s/d -54 & Buruk \\
\hline-55 s/d -70 & Buruk Sekali \\
\hline
\end{tabular}

Indeks STORET memiliki kekurangan dan kelebihan dibandingkan dengan indeks kualitas air lainnya. Kekurangan yang dimiliki adalah tidak adanya jumlah parameter tetap yang harus digunakan dalam perhitungan, sehingga perhitungan indeks dengan jumlah parameter yang berbeda akan memiliki gambaran yang berbeda. Semakin banyak parameter kualitas air yang digunakan dalam perhitungan indeks STORET, akan semakin tepat gambaran kualitas air yang diperoleh. Kelebihan dari indeks STORET adalah dapat menggabungkan sejumlah data parameter kualitas air, sehingga gambaran mengenai kualitas air akan lebih komprehensif dan tidak tergantung kepada parameter tertentu.

\subsubsection{Indeks Similaritas Canberra}

Indeks Similaritas Canberra digunakan untuk melihat kesamaan antar stasiun pengamatan berdasarkan parameter fisika-kimia air yang dilakukan melalui sistem pengelompokan. Nilai yang diperoleh kemudian dikelompokkan dengan menggunakan sidik gerombol hirarki metode rataan ikatan kelompok. Kelompok-kelompok ini kemudian di plot dalam bentuk dendogram. Rumus yang digunakan adalah sebagai berikut (Clarck, 1974; Cancter, 1977; Clarck, 1986; Welch, 1980; Novonty and Olem, 1994):

$$
I c=1-\frac{1}{n}\left[\sum_{i=1}^{n}\left(\left|\frac{X i j-X i k}{X i j+X i k}\right|\right)\right]
$$

Keterangan :

Ic : Nilai kesamaan indeks Canberra.

$N$ : Jumlah parameter yang diperbandingkan.

$X i j, X i k$ :Nilai parameter fisika kimia yang ke-I pada dua tempat yang berbeda.

Prinsip pengelompokkan indeks Canberra dilakukan dengan cara mencari nilai korelasi antar stasiun, sehingga setiap stasiun akan memiliki nilai korelasi dengan semua stasiun lain. Nilai korelasi antara stasiun tersebut selanjutnya disusun dalam sebuah matriks yang disebut Matriks Similaritas Canberra. Hasil perhitungan indeks similaritas Canberra kemudian ditampilkan dalam bentuk plot dendogram berdasarkan keterkaitan antara kelompok. Hasil dari plot dendodram ini akan menggambarkan tingkat kemiripan habitat antara beberapa stasiun pengamatan dengan melihat nilai masing-masing parameter. Perhitungan indeks Similaritas Canberra dalam penelitian ini dilakukan berdasarkan hasil rata-rata dari tiga kali pengamatan.

\section{ASIL DAN PEMBAHASAN}

\subsection{Evaluasi Kualitas Air Perairan Pulau Abang dengan Indeks STORET}

Indeks STORET merupakan salah satu cara untuk mengevaluasi kualitas suatu perairan. Dengan menggunakan analisa Indeks STORET, maka dapat diketahui pula parameter-parameter yang telah melampaui baku mutu berdasakan Kep.Men. LH No.51 Tahun 2004 bagi kehidupan biota laut. Hasil analisis Indeks STORET telah menunjukkan bahwa parameter yang sesuai dengan baku mutu laut adalah suhu, salinitas, kecerahan, TSS, DO, pH, ortofosfat dan ammonia pada tiap lapisan perairan. Hasil evaluasi kualitas air di perairan Pulau Abang pada bulan Mei, Juni dan Oktober 2006 seperti terlihat pada Gambar 3, menunjukkan bahwa kondisi kualitas di Perairan Pulau Abang tergolong layak bagi kehidupan biota laut. Kondisi pada bulan Mei 2006 tergolong baik pada tiap lapisan, dengan skor $-5 \mathrm{~s} / \mathrm{d}-12$. Kondisi ini menunjukkan bahwa kualitas air di perairan Pulau Abang berdasarkan baku mutu biota laut, berada dalam kondisi tidak tercemar.

Kemudian pada bulan Juni 2006, kondisi kualitas perairan di Pulau Abang tergolong tercemar sedang pada lapisan permukaan dan 
dasar dengan skor masing-masing sebesar -25 . Perubahan kondisi perairan Pulau Abang pada bulan Juni 2006, diduga karena mendapat masukan bahan organik yang berasal dari pembusukan sisa-sisa detritus dan limpasan buangan limbah rumah tangga yang masuk ke perairan. Hal ini dapat terlihat dari hasil analisis Indeks STORET yang menunjukkan bahwa parameter yang telah melampaui buku mutu biota laut adalah TSS, DO dan ammonia.

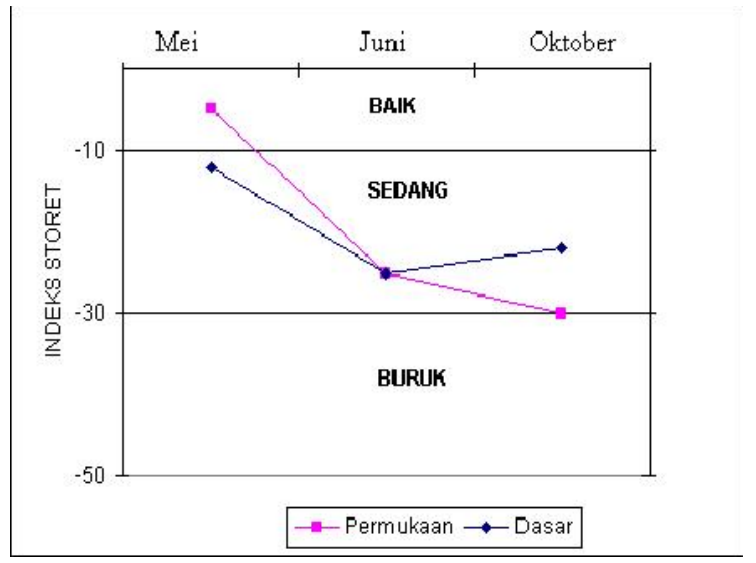

Gambar 3. Evaluasi Kualitas Air Di Perairan Pulau Abang Pada Bulan Mei, Juni Dan Oktober 2006

Sedangkan kondisi kualitas perairan pada bulan Oktober 2006, tidak berbeda jauh dengan bulan Mei 2006. Berdasarkan baku mutu untuk biota laut, kondisi kualitas air Perairan Pulau Abang tergolong tercemar sedang di lapisan permukaan dan dasar, dengan skor -22 $\mathrm{s} / \mathrm{d}$-30. Kondisi kualitas air Perairan Pulau Abang tergolong tercemar sedang karena beberapa parameter seperti TSS, DO dan ammonia melampaui baku mutu kehidupan biota laut yang diperbolehkan.

\subsection{Kesamaan Antar Stasiun Berdasarkan Parameter Fisika-Kimia}

\subsubsection{Kesamaan Antar Stasiun Pada Bulan Mei 2006}

Untuk mengetahui kesamaan kondisi lingkungan antar stasiun, maka digunakan Indeks Similaritas Canberra berdasarkan parameter fisika-kimia. Pengelompokkan ini dilakukan dengan menggunakan 11 parameter, yaitu suhu, salinitas, TSS, TDS, pH, DO, ammonia, nitrat, nitrit, ortofosfat dan COD. Hasil pengamatan pada bulan Mei 2006 menunjukkan bahwa di lapisan permukaan, pengelompokkan stasiun dengan taraf kesamaan sebesar $85,87 \%$, kondisi lingkungan Perairan Tanah Abang terbagi menjadi 4 kelompok (Gambar 4). Kelompok I terdiri dari stasiun 2, 5, 6, 3 dan 4; kelompok II, stasiun 8; kelompok III, stasiun 1; dan kelompok IV, stasiun 7 .

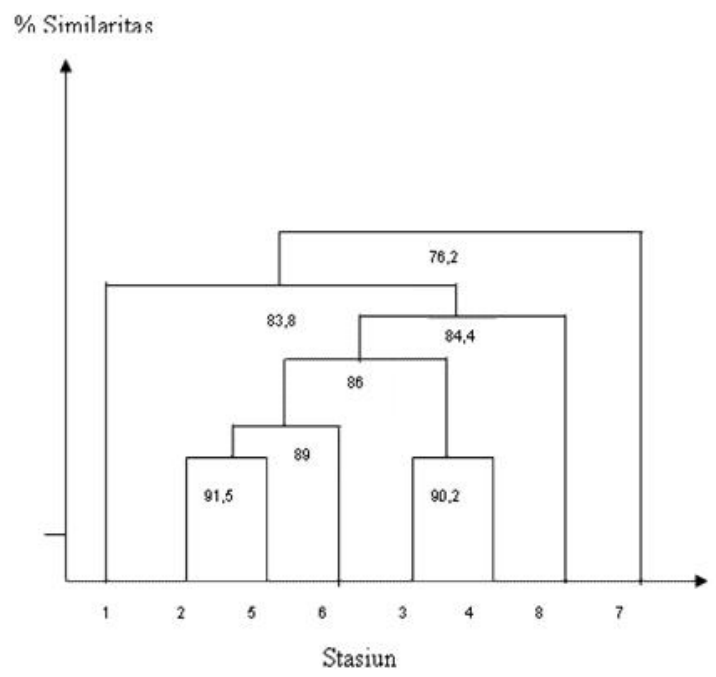

Gambar 4. Dendrogram Kesamaan Antar Stasiun Di Lapisan Permukaan Perairan Pulau Abang Pada Bulan Mei 2006

Stasiun 2, 5, 6, 3 dan 4 membentuk satu kelompok, diduga karena adanya kesamaan dalam parameter nitrit. Nilai nitrit pada stasiun tersebut merupakan nilai nitrit yang rendah dibandingkan dengan stasiun-stasiun lainnya, yang berkisar antara 0,0014-0,003 mg/l. Stasiun 8 mengelompok sendiri, diduga karena memiliki parameter COD tertinggi dan nitrat terendah dibandingkan dengan stasiun-stasiun lainnya. Nilai COD dan nitrat masing-masing sebesar 72 $\mathrm{mg} / \mathrm{l}$ dan $0,35 \mathrm{mg} / \mathrm{l}$. Stasiun 1 mengelompok sendiri, diduga karena memiliki parameter nitrit dan TDS tertinggi yaitu masing-masing sebesar $0,0047 \mathrm{mg} / \mathrm{l}$ dan $31.100 \mathrm{mg} / \mathrm{l}$. Stasiun 7 mengelompok sendiri, diduga karena memiliki parameter ammonia , TSS, dan DO tertinggi dibandingkan dengan stasiun-stasiun lainnya. Nilai ammonia, TSS dan DO masing-masing sebesar 0,442 mg/l, $32 \mathrm{mg} / \mathrm{l}$ dan 5,95 mg/l.

Berdasarkan hasil pengamatan pada bulan Mei 2006, dilapisan dasar Perairan Pulau Abang dengan taraf kesamaan sebesar $88,04 \%$, terbagi menjadi 5 kelompok (Gambar 5). Kelompok I, stasiun 1 dan 5; kelompok II, stasiun 2, 4 dan 8; kelompok III, stasiun 3; kelompok IV, stasiun 6; dan kelompok V, stasiun 7. Stasiun 1 dan 5 membentuk satu kelompok, diduga karena adanya kesamaan parameter COD yang tinggi dibandingkan dengan stasiun lainnya yang berkisar antara 50-62 $\mathrm{mg} / \mathrm{l}$ dan memiliki parameter ammonia yang rendah dibandingkan dengan stasiun lainnya yang berkisar antara 0,153-0,204 mg/l. 


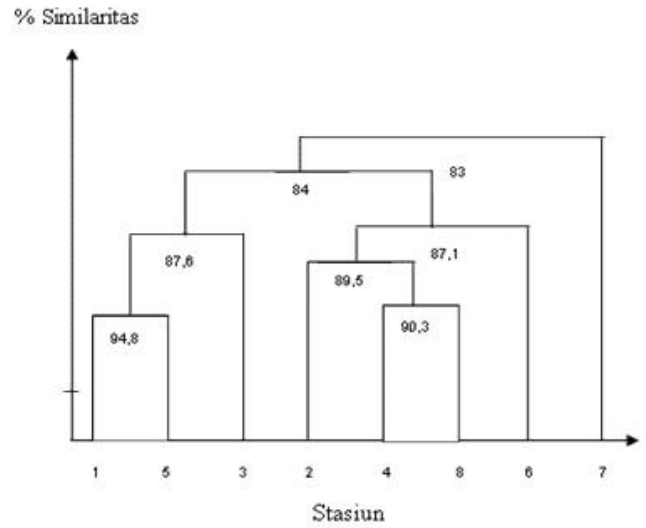

Gambar 5. Dendrogram Kesamaan Antar Stasiun Di Lapisan Dasar Perairan Pulau Abang Pada Bulan Mei 2006

Stasiun 2, 4, dan 8 membentuk satu kelompok, diduga karena adanya kesamaan dalam parameter nitrit. Nilai nitrit pada stasiun tersebut merupakan nilai nitrit yang tertinggi dibandingkan dengan stasiun-stasiun lainnya, yaitu berkisar antara 0,0018-0,0047 mg/l. Stasiun 3 mengelompok sendiri, diduga karena memiliki parameter TSS yang rendah dibandingkan dengan stasiun-stasiun lainnya yaitu sebesar 20 $\mathrm{mg} / \mathrm{l}$. Stasiun 6 mengelompok sendiri, diduga karena memiliki parameter ammonia dan TDS yang tinggi dibandingkan dengan stasiun-stasiun lainnya masing-masing sebesar $0,371 \mathrm{mg} / \mathrm{l}$ dan $27650 \mathrm{mg} / \mathrm{l}$. Stasiun 7 mengelompok sendiri, diduga karena memiliki parameter salinitas dan DO tertinggi dibandingkan dengan stasiun stasiun lainnya yang masing-masing bernilai 32,4 psu dan $5,9 \mathrm{mg} / \mathrm{l}$.

\subsubsection{Kesamaan Antar Stasiun Pada Bulan Juni 2006}

Dalam pengamatan bulan Juni 2006 dengan taraf kesamaan sebesar $92,27 \%$; Kondisi kualitas Perairan Pulau Abang, terbagi menjadi 3 kelompok (Gambar 6). Kelompok I, stasiun 1, 4, 7 , 2 , 5, dan 3; kelompok II, stasiun 6; dan kelompok III, stasiun 8 .

Stasiun 1, 4, 7, 2 , 5, dan 3 membentuk satu kelompok, diduga karena adanya kesamaan dalam parameter ortofosfat yang rendah dibandingkan dengan stasiun-stasiun lainnya. Nilai otofosfat di stasiun tersebut masing-masing sekitar $<0,001 \mathrm{mg} / \mathrm{l}$. Stasiun 8 mengelompok sendiri, diduga karena memiliki parameter ammonia, ortofosfat tinggi serta nitrat dan $\mathrm{pH}$ rendah dibandingkan dengan stasiun-stasiun lainnya. Nilai ammonia dan orotofosfat masing-masing sebesar $1,126 \mathrm{mg} / \mathrm{l}$ dan 0,072 $\mathrm{mg} / \mathrm{l}$ sedangkan nilai TDS dan $\mathrm{pH}$ masing-masing sebesar $28.800 \mathrm{mg} / \mathrm{l}$ dan 7,65. Stasiun 6 mengelompok sendiri, diduga karena memiliki parameter $\mathrm{pH}$, nitrit, $\mathrm{COD}$ dan TDS tertinggi yaitu masing-masing sebesar 8,$1 ; 0,0278 \mathrm{mg} / \mathrm{l}$; $64 \mathrm{mg} / \mathrm{l}$ dan $44.000 \mathrm{mg} / \mathrm{l}$ serta memiliki parameter nitrat terendah yaitu sebesar $0,021 \mathrm{mg} / \mathrm{l}$.

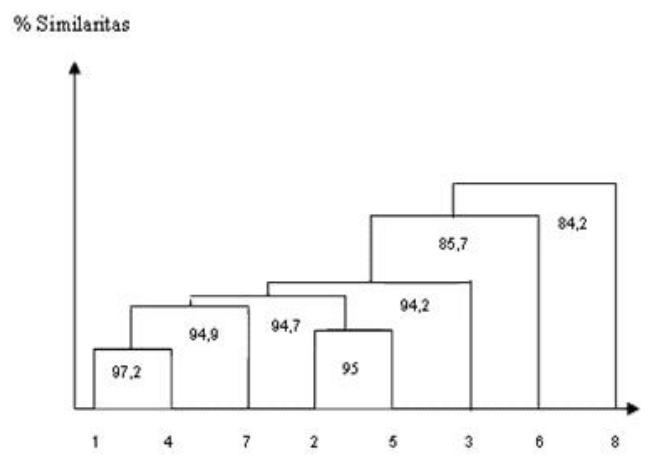

Gambar 6. Dendrogram Kesamaan Antar Stasiun Di Lapisan Permukaan Perairan Pulau Abang Pada Bulan Juni 2006

Berdasarkan hasil pengamatan pada bulan Juni 2006, pengelompokkan di lapisan dasar Perairan Pulau Abang dengan taraf kesamaan sebesar $83,77 \%$, terbagi menjadi 4 kelompok (Gambar 7). Kelompok I, stasiun 1, 3 dan 8; kelompok II, stasiun 2, 5 dan 4; kelompok III, stasiun 6; dan kelompok IV, stasiun 7 .

Stasiun 1, 3 dan 8 membentuk satu kelompok, diduga karena adanya kesamaan parameter nitrat dan $\mathrm{pH}$ yang tinggi dibandingkan dengan stasiun lainnya yang masing-masing berkisar antara 0,026-0,079 mg/l dan 8,04-8,23 serta memiliki parameter ortofosfat yang rendah dibandingkan dengan stasiun lainnya sebesar < $0,001 \mathrm{mg} / \mathrm{l}$. Stasiun 2, 5, dan 4 membentuk satu kelompok, diduga karena adanya kesamaan dalam parameter ammonia, COD dan ortofosfat yang merupakan parameter tertinggi dibandingkan dengan stasiun-stasiun lainnya, yaitu masing-masing berkisar antara 0,83-1,545 $\mathrm{mg} / \mathrm{l}, 52-62 \mathrm{mg} / \mathrm{l}$ dan 0,007-0,045 mg/l.

Stasiun 6 mengelompok sendiri, diduga karena memiliki parameter TSS yang rendah dibandingkan dengan stasiun-stasiun lainnya yaitu sebesar $20 \mathrm{mg} / \mathrm{l}$. Stasiun 6 mengelompok sendiri, diduga karena memiliki parameter COD yang rendah dibandingkan dengan stasiun stasiun lainnya masing-masing sebesar $4 \mathrm{mg} / \mathrm{l}$. Stasiun 7 mengelompok sendiri, diduga karena memiliki parameter ammonia rendah dibandingkan dengan stasiun-stasiun lainnya sebesar $0,0024 \mathrm{mg} / \mathrm{l}$ serta memiliki nitrit tertinggi dibandingkan dengan stasiun-stasiun lainnya yaitu sebesar $0,0337 \mathrm{mg} / \mathrm{l}$.

\subsubsection{Kesamaan Antar Stasiun Pada Bulan Oktober 2006}

Hasil pengamatan pada bulan Oktober 2006 dengan taraf kesamaan sebesar $86,41 \%$; 
kondisi kulaitas Perairan Pulau Abang, terbagi menjadi 3 kelompok (Gambar 8). Kelompok I, stasiun 4, 6, 5 dan 7; kelompok II, stasiun 1 dan 3; kelompok III, stasiun 2 ; dan kelompok IV stasiun 8. Stasiun 4, 6, 5 dan 7 membentuk satu kelompok, diduga karena adanya kesamaan dalam parameter nitrit, COD dan ortofosfat yang merupakan parameter tertinggi dibandingkan dengan stasiun-stasiun lainnya, yaitu masing-masing berkisar antara 0,83-1,545 $\mathrm{mg} / \mathrm{l}$, 52-62 mg/l dan 0,007-0,045 mg/l.

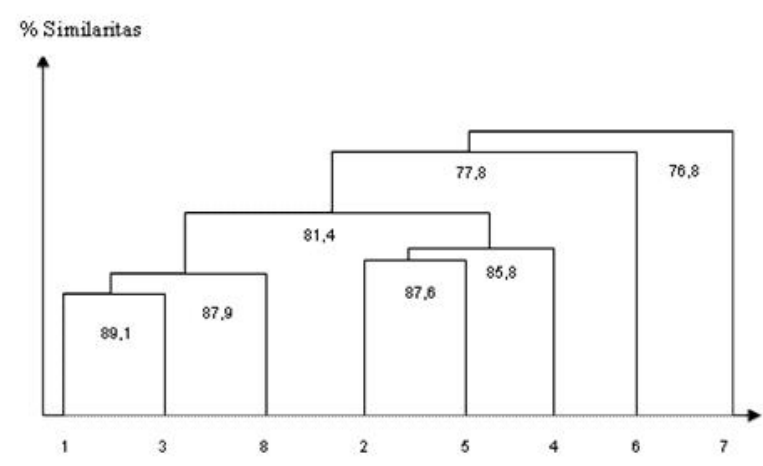

Gambar 7. Dendrogram Kesamaan Antar Stasiun Di Lapisan Dasar Perairan Pulau Abang Pada Bulan Juni 2006

Stasiun 6 mengelompok sendiri, diduga karena memiliki parameter TSS yang rendah dibandingkan dengan stasiun-stasiun lainnya yaitu sebesar $20 \mathrm{mg} / \mathrm{l}$. Stasiun 6 mengelompok sendiri, diduga karena memiliki parameter COD yang rendah dibandingkan dengan stasiun-stasiun lainnya masing-masing sebesar 4 $\mathrm{mg} / \mathrm{l}$. Stasiun 7 mengelompok sendiri, diduga karena memiliki parameter ammonia rendah dibandingkan dengan stasiun-stasiun lainnya sebesar $0,0024 \mathrm{mg} / \mathrm{l}$ serta memiliki nitrit tertinggi dibandingkan dengan stasiun-stasiun lainnya yaitu sebesar $0,0337 \mathrm{mg} / \mathrm{l}$.

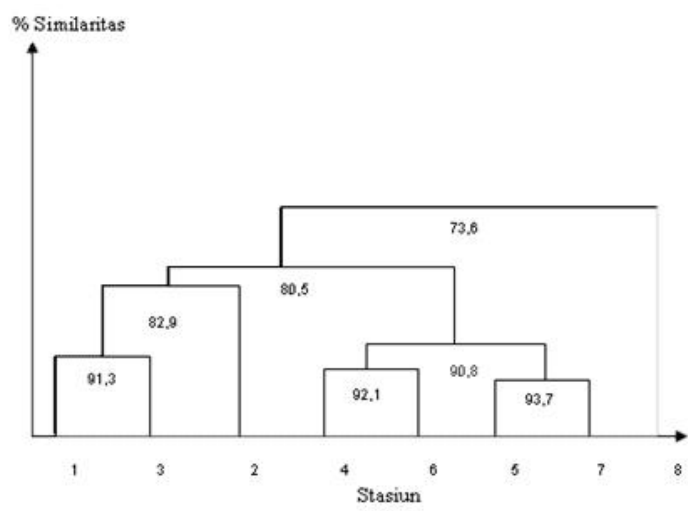

Gambar 8. Dendogram Kesamaan Antar Stasiun Di Lapisan Permukaan Pulau Abang Pada Bulan Oktober 2006
Pada pengamatan bulan Oktober 2006 di lapisan dasar, dengan taraf kesamaan sebesar 81,17\%; kondisi lingkungan Perairan Pulau Abang terbagi menjadi $\vee$ kelompok (Gambar 9). Kelompok I, stasiun 2 dan 3; kelompok II, stasiun 7 dan 8; kelompok III, stasiun 1 dan 4; kelompok IV, stasiun 6; dan kelompok V, stasiun 5. Stasiun 2 dan 3 membentuk satu kelompok, diduga karena adanya kesamaan dalam parameter salinitas yang tinggi dibandingkan dengan stasiun-stasiun lainnya, yaitu berkisar 31,7-32 psu, serta memiliki parameter TSS dan ortofosfat yang rendah dibandingkan dengan stasiun-stasiun lainnya, yaitu masing-masing berkisar antara 6-13 mg/l, dan 0,004-0,005 mg/l.

Stasiun 7 dan 8 membentuk satu kelompok, diduga karena memiliki parameter ammonia yang rendah dibandingkan dengan stasiun-stasiun lainnya yaitu berkisar antara 0,108-0,247 mg/l, serta memiliki parameter ortofosfat yang tinggi dibandingkan dengan stasiun lainnya yaitu $0,0015-0,0016 \mathrm{mg} / \mathrm{l}$. Stasiun 1 dan 4 mengelompok sendiri, diduga karena memiliki parameter COD dan TDS yang tinggi dibandingkan dengan stasiun-stasiun lainnya, yaitu masing-masing berkisar antara $52,98-102,89 \mathrm{mg} / \mathrm{l}$ dan 18.000-31.950 mg/l. Stasiun 6 mengelompok sendiri, diduga karena memiliki parameter COD dan DO rendah dibandingkan dengan stasiun-stasiun lainnya masing-masing sebesar $4 \mathrm{mg} / \mathrm{l}$ dan $3,1 \mathrm{mg} / \mathrm{l}$, serta memiliki nitrit tertinggi dibandingkan dengan stasiun-stasiun lainnya yaitu sebesar $0,0337 \mathrm{mg} / \mathrm{l}$. Stasiun 5 mengelompok sendiri, diduga karena memiliki parameter TSS dan DO tinggi dibandingkan dengan stasiun lainnya masing-masing sebesar $73 \mathrm{mg} / \mathrm{l}$ dan 3,6 mg/l.

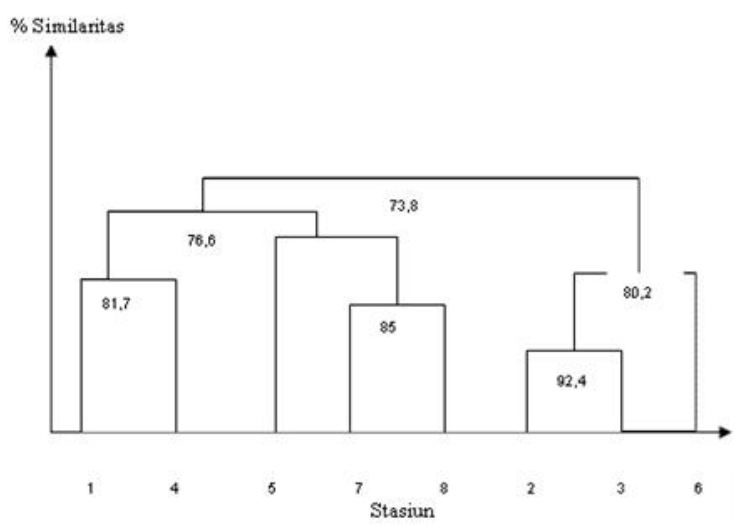

Gambar 9. Dendrogram Kesamaan Antar Stasiun Di Lapisan Dasar Perairan Pulau Abang Pada Bulan Oktober 2006

\section{KESIMPULAN}

Secara umum kondisi kualitas air di Perairan Pulau Abang cukup baik dan mendukung kehidupan biota laut. Berdasarkan Keputusan Menteri Lingkungan Hidup No. 51 Tahun 2004, 
dapat dikatakan bahwa Perairan Pulau Abang pada bulan Mei 2006 tergolong baik bagi kehidupan biota laut di tiap lapisan perairan. Kondisi tersebut dapat terlihat dari beberapa parameter kualitas air yang sesuai dengan baku mutu yang diperbolehkan seperti $\mathrm{DO}$, suhu, $\mathrm{pH}$, salinitas, ammonia, kecerahan dan ortofosfat.

Pada pengamatan bulan Juni 2006, kondisi Perairan Pulau Abang mengalami perubahan. Hasil analisis beberapa parameter yang diamati pada bulan Juni 2006, menujukkan bahwa perairan Pulau Abang berada dalam kondisi tercemar sedang di lapisan permukaan dan dasar. Kondisi tersebut dapat terlihat dari beberapa parameter kualitas air yang melebihi nilai baku mutu untuk biota laut, seperti parameter ammonia, DO dan TSS.

Pada pengamatan bulan Oktober 2006, kondisi perairan Pulau Abang berdasarkan Indeks STORET hampir sama dengan bulan Juni 2006, yaitu berada dalam kondisi tercemar sedang di tiap lapisan perairan yang dikarenakan terdapat beberapa parameter kualitas air yang melampaui baku mutu biota laut, seperti ammonia, DO dan TSS.

Hasil analisis Indeks Similaritas Canberra menujukkan, pada umumnya stasiun yang membentuk satu kelompok adalah stasiun yang berada dalam area yang sama.

\section{DAFTAR PUSTAKA}

1. APHA (American Public Health Assciation) 1989, Standard methods for the examination of water and wastewater, $17^{\text {th }}$ ed. APHA, AWWA and WPCF Inc. Washington DC.

2. Bappeko 2006, Master plan pengembangan Batam Marikultur Estat. Bappeko. Batam.

3. Canter, W. L. 1977, Enviromental Impact Assesment. Mc Graw-Hill Company, USA.

4. Clark, J. 1974, Coastal ecosystem ecological. Consideration for Management of the Coastal Zone, The Conservation Foundation. Washington DC.

5. Clark, J. 1986, Marine Pollution. Clarendon. Press-oxford.

6. Menteri Lingkungan Hidup 2004, Keputusan Kantor Menteri Negara Lingkungan Hidup No.51/MENLH///2004, Tentang Pedoman Penetapan Baku Mutu Lingkungan.

7. Moriber, G. 1974, Enviromental science. Brooklyn College. Allyn and Bacon Inc., Boston

8. Nontji, A. 1987, Laut Nusantara, Penerbit Djembatan - Jakarta.

9. Novonty V dan H Olem 1994, Water Quality: management of diffuse pollution, New York: Van Nostrand Reinhold. 735-765 hal .

10. Tomascik T, AJ Mah, A Nontji dan MK Moosa 1997, Enviromental Management
Development in Indonesia. Part one. Scholl Of Resources and Enviromental Studies, Dalhousie Unversity. Canada. 642 hal

11. Welch, E. B. 1980, Ecologycal Effects of Waste water, Cambridge. 